\title{
СИСТЕМА УПРАВЛІННЯ ЯКІСТЮ ЯК ІНСТРУМЕНТ УДОСКОНАЛЕННЯ МЕНЕДЖМЕНТУ ТУРИСТСЬКОГО ПІДПРИЕМСТВА
}

\section{QUALITY MANAGEMENT SYSTEM AS A TOOL FOR THE IMPROVEMENT OF TRAVEL COMPANY MANAGEMENT}

\author{
Чорна Наталія Миколаївна \\ доктор історичних наук, профресор, \\ Вінницький торговельно-економічний інститут \\ Київського національного торговельно-економічного університету \\ ORCID: https://orcid.org/0000-0002-6709-6364
}

\author{
Chorna Nataliia \\ Vinnytsia Institute of Trade and Economics \\ of Kyiv National University of Trade and Economics
}

\begin{abstract}
У статті проаналізовано теоретико-методичні та практичні аспекти впровадження та фрунціонування на туристському підприємстві системи управління якістю, відповідної міжнародному стандарту ISO 9001. 3роблено короткий екскурс у генезис теорії управління якістю. Обґрунтовано переваги, що їх отримують підприємства (організації) від функціонування системи менеджменту якості та доведено необхідність її впровадження. Увагу зосереджено на проблемі сертисрікаційного аудиту, за результатами якого підприємству може бути виданий сертифрікат відповідності вимогам стандарту ISO 9001. Констатовано, що для туристського підприємства сертифрікація на відповідність стандарту ISO 9001 є не обов'язковою, але бажаною, адже засвідчує високу якість системи менеджменту якості, яка безпосередньо впливає на якість надаваних послуг, забезпечує конкурентоспроможність підприємства на ринку галузі.
\end{abstract}

Ключові слова: система управління якістю, менеджмент якості, туристське підприємство, конкурентоспроможність.

В статье проанализированы теоретико-методические и практические аспекты внедрения и сункционирования на туристском предприятии системы управления качеством, соответствующей международному стандарту ISO 9001. Сделано краткий экскурс в генезис теории управления качеством. Обоснованно преимущества, которые получают предприятия (организации) от функционирования системы менеджмента качества, доказано необходимость ее внедрения. Внимание сосредоточено на проблеме сертисикационного аудита, по результатам которого предприятию может быть выдан сертификат соответствия требованиям стандарта ISO 9001. Констатировано, что для туристского предприятия сертификация на соответствие стандарту ISO 9001 является не обязательной, но желательной, ведь свидетельствует о высоком качестве системы менеджмента качества, непосредственно влияет на качество предоставляемых услуг, обеспечивает конкурентоспособность предприятия на рынке отрасли.

Ключевые слова: система управления качеством, менеджмент качества, туристское предприятие, конкурентоспособность.

The article has analyzed the theoretical and methodological and practical aspects of implementation and operation of a quality management system at the travel company in compliance with the international standard ISO 9001 . We have carried out a brief insight into the genesis of the quality management theory and identified that more developed, competitive economic systems are peculiar to the countries where business entities have long-standing traditions in accordance with the requirements of the ISO standard, in contrast to those whose companies (organizations) are just beginning to move by means of introducing the TQM system. We have substantiated the advantages received by the companies (organizations) resulted from the operation of the quality management and established the necessity of its implementation. Attention is drawn to the problems of certification audit, as a result of which certificate of conformity to the requirements of ISO 9001 may be issued to the company. It has been indicated that the ISO 9001 standard does not exist directly for the tourism industry as such. Therefore, if the travel company is under certification 
audit, in this case the principles of ISO 9001 standard, common to all, shall be applied, except for certain items, which shall be analyzed very thoroughly, while some others, on the contrary, shall be omitted. It has been stated that certification of conformity to ISO 9001 is not mandatory for the travel company, but desired, because it certifies the high quality of the quality management system, which directly affects the quality of services provided, determines the competitive ability of the company in the industry sector market and ensures to some extent the prospects of its sustainable development for the near future. Besides, available certificate does not mean that the company has reached a certain level and can stop at the achieved results: in order to remain in high demand among consumers, the travel company must constantly work over the improvement of the quality of services. Therefore, the certificate of conformity to the requirements of the international standard ISO 9001 for tourism is a sign of quality that must be confirmed on a regular basis.

Keywords: quality management system, quality management, tourism enterprise, competitiveness.

Постановка проблеми. Аби досягти визначених результатів діяльності та зайняти на ринку галузі гідну позицію, будь-яке підприємство (організація) повинно мати ефективно фрункціонуючу систему менеджменту якості.

Як свідчить генезис теорії управління якістю, оформлення основних ії положень відбулося у XX ст., значно під впливом та у зв'язку з досягненнями американських та японських підприємців, фрахівців 3 менеджменту та науковців (Г. Форд, Ф. Тейлор, Дж. Джуран, К. Ісакава, Е. Демінг, Ф. Кросбі, Г. Тагуті, ін.). У середині $\mathrm{XX}$ ст. завдяки їхнім напрацюванням стало можливим започаткування епохи тотального управління якістю Total Quality Management (TQM). Упровадження на виробництві системи TQM, безсумнівно, неабияк посприяло тривалому економічному розвитку у багатьох капіталістичних країнах світу, який тривав, орієнтовно, від започаткування плану Маршала та БреттонВудської системи до насртової кризи 1973 р.

Досвід США, а також Японії, Німеччини, Швеції, ін. свідчить: для досягнення успіху, забезпечення якості товарів, послуг, робіт має стати національною ідеєю та набути загального характеру, охопивши всі версти населення, від учнів та студентів до зайнятих на виробництві працівників, від рядових споживачів до керівників вищої ланки. Так, у розвинутих країнах світу проблеми якості наразі вирішуються системно, відповідно до міжнародних стандартів управління якістю (далі - СУя) ISO 9000, водночас, в Україні, тотожно багатьом іншим країнам пострадянського простору, цілісна ідеологія якості відсутня. При цьому не викликає заперечень той фракт, що саме підвищення якості та конкурентоспроможності продукції національних товаровиробників за рахунок пріоритетного вирішення проблем якості спроможне закласти потужний фрундамент економічного зростання в Україні.

Аналіз останніх досліджень і публікацій. Обрана для дослідження проблема у наукових розвідках представлена щонайменше у двох взаємопов'язаних площинах: 3 однієї сторони, йдеться про праці, у яких предметом дослід- ницького пошуку стали аспекти проблеми впровадження та фуункціонування на підприємствах системи управління якістю, 3 іншої, - питання якості послуг, надаваних туристськими підприємствами. Як уже зазначалося, фрундаментальні дослідження проблеми управління якістю на підприємствах (організаціях) були започатковані американськими та японськими фрахівцями (Дж. Джуран, А. Фейгенбаун, К. Ісакава, Е. Демінг, Ф. Кросбі, ін.). У наш час вивчення аспектів проблеми продовжується, зокрема, в Україні над нею працюють О. Апілат, А. Астахов, О. Баклан, А. Глєбова, Л. Горшков, А. Дубодєлова, С. Ізотов, І. Лебедєв, Н. Обловацька, К. Фісун, Л. Хриплива, ін. Що стосується проблеми управління якістю послуг туристських підприємств, вітчизняні дослідники почали працювати над її вивченням відносно недавно. Станом на тепер доробок за тематикою представлений студіями В. Баєва, Г. Бедрадіної, М. Босовської, М. Кривоберець, О. Оливко, І. Сидоренко, ін.

Виділення невирішених раніше частин загальної проблеми. Водночас, ґрунтовні дослідження проблеми впровадження та фрункціонування на туристських підприємствах системи управління якістю, відповідної вимогам міжнародного стандарту ISO серії 9000 (9001), наразі фрактично відсутні.

Формулювання цілей статті. Метою даної публікації $€$ дослідження теоретикометодичних та прикладних аспектів фрункціонування на підприємствах (організаціях) системи управління якістю, відповідної міжнародному стандарту ISO серії 9000 (9001), обґрунтування доцільності її впровадження у діяльність туристських підприємств.

Виклад основного матеріалу дослідження. Стандарти ISO серії 9000 (пізніше - 9001) були задумані та прийняті світовим товариством, перш за все, як універсальні критерії, завдяки яким можна оцінити можливість підприємств (організацій) стабільно виробляти продукцію, якість якої відповідає вимогам споживачів [1, с. 60]. Наразі зазначені стандарти прийняті у понад 90 країнах 
світу і застосовуються підприємствами незалежно від їхнього розміру, організаційно-правової форми чи ссрери діяльності. Світовими лідерами у ссрері стандартизації управління якістю $є$ Китай, Італія, Японія, Велика Британія, США, Індія, Франція та Німеччина.

Міжнародний стандарт ISO 9001 встановлює вимоги до систем управління якістю (СУя) для підприємств (організацій), діяльність яких спрямовується на досягнення довготривалого успіху через задоволення вимог споживачів та отримання вигоди як персоналом підприємства, так і суспільством загалом [2].

Як відомо, фрункціонування на підприємстві (організації) системи менеджменту якості дозволяє йому отримати низку переваг, серед яких:

- орієнтація на досягнення цілей діяльності з урахуванням інтересів зацікавлених сторін;

- ефективне та раціональне використання ресурсів;

- зменшення можливих протиріч між різними аспектами діяльності;

- залучення більшої кількості співробітників до управління якістю;

- створення єдиної системи управління документацією і ведення записів;

- збільшення числа лояльних споживачів;

- зміцнення конкурентної позиції на ринку галузі й забезпечення сталого розвитку;

- покращення іміджу, ін. [3, с. 356].

СУя ґрунтується на принципах загального управління якістю і системному підході та передбачає, що якість продукції, виробленої підприємством, залежить від усіх видів провадженої ним діяльності.

Найважливішими принципами загального управління якістю, які забезпечують успіх стратегії якості, $€$ [1]:

- акцент на споживача, який передбачає спрямування всієї уваги виробника на задоволення запитів і побажань споживача, котрий $€$ учасником процесу, здійснюваного виробником, та арбітром в оцінюванні його якості. Аби орієнтуватися у смаках та вподобаннях споживачів, які $€$ дуже мінливими, необхідним $€$ постійне системне їх дослідження;

- залучення вищого керівництва до безпосередньої участі у фрункціонуванні системи та подання відповідного прикладу. Керівництво має чітко визначати цілі та політику у сорері якості, формувати високі очікування у працівників, гарантувати якість виготовленої продукції споживачам;

- акцент на процес. Згідно СУЯ, процес-це будь-яка організована діяльність із трансформування фракторів входу у попередньо спланований для відповідного споживача вихід (продукт, послугу). Кожен процес повинен мати свого керівника, який має відповідати за поліпшування роботи та може самостійно приймати рішення. Процес розглядається як джерело якості, тому якість процесу фрактично є якістю результату процесу. Це означає, що необхідно впливати на процес, а не на його результати, щоб не виправляти допущені помилки (дефректи), а упереджувати їх;

- постійне поліпшування. Виходячи 3 того, що конкуренція на ринку галузі постійно зростає, а потреби та очікування споживачів постійно змінюються, якість вихідного продукту потребує постійного поліпшування;

- залучення до роботи 3 поліпшування якості усіх учасників процесу. Йдеться про персонал та споживачів, які заради забезпечення високої якості продукції повинні брати безпосередню участь у процесах поліпшування;

- прийняття рішень з урахуванням фрактів. Рішення будуть ефективними, якщо вони базуватимуться на срактах, а результати мають бути вимірюваними (йдеться про плани робіт, які повинні формувати усі відділи на календарний рік, а потім аналізувати їх виконання) [7, с. 78-80].

Система, як відомо, - це сукупність взаємопов'язаних елементів, які утворюють єдине ціле, взаємодіють із середовищем та між собою, і мають спрямовуються на досягнення визначеної мети. Якість, згідно Міжнародного стандарту ISO 8420 (Управління якістюі забезпечення якості. Словник), - це сукупність характеристик об'єкта, які належать до його властивості задовольнити встановлені та передбачувані потреби. Управління якістю, своєю чергою, полягає в координуванні дій щодо спрямування та контролювання діяльності підприємства (організації) стосовно якості, які носять системний характер. Відповідно, система управління якістю - це сукупність взаємопов'язаних та/або взаємодіючих елементів підприємства (організації), які дають змогу спрямовувати та контролювати діяльність організації щодо якості.

Системний підхід до управління якістю передбачає формування цільової підсистеми управління підприємством (організацією) як упорядкованої сукупності взаємопов'язаних і взаємодіючих елементів, призначених для досягнення поставленої мети - створення умов для забезпечення необхідного рівня якості товарів, послуг, робіт при мінімальних витратах.

В основі системного підходу перебувають наступні принципи:

- цілеспрямованості - дозволяє встановити межі управління і адресність управлінських рішень; 
- комплексності - охоплює всі стадії життєвого циклу продукту, всі структурні підрозділи, керівництво і весь персонал підприємства;

- безперервності - забезпечує процес управління, орієнтований на постійне поліпшення системи;

- об'єктивності - орієнтує на використання адекватних методів управління, вибір показників, що відображають дійсний стан управління якістю, підбір управлінського персоналу відповідної кваліфрікації;

- оптимальності - передбачає необхідність забезпечення результативності та ефективності процесів управління якістю, зокрема, і системи в цілому [4].

Стандарт ISO 9001 визначає загальні вимоги до того, як повинна бути побудована система обліку та управління на підприємстві, щоб воно могло гарантувати роботу виробничої системи відповідно до вимог системи якості. Насправді цей стандарт не може забезпечити гарантованої якості продукції, що випускається, але покликаний забезпечити гарантоване усунення недоліків процесу виробництва, які суттєво впливають на якість продукції.

Здатність підприємства (організації) відповідати вимогам стандарту ISO 9001 підтверджується шляхом проходження процедури сертиорікації та отримання сертиоріката відповідності від незалежних компетентних і уповноваженими на це міжнародних і національних органів. Кожного року упродовж терміну дії сертисрікату командою аудиторів на підприємстві (організації) проводиться наглядовий аудит, завданням якого $є$ забезпечення постійної відповідності системи менеджменту якості вимогам міжнародного стандарту ISO 9001 та неухильне її поліпшування.

Універсальний за своїм змістом, стандарт ISO 9001 широко застосовується не тільки в промисловому секторі економіки, а й у таких галузях, як авіація, телекомунікації, освіта, охорона здоров'я, органи управління, ссрера гостинності та туризму тощо.

Туристична галузь, будучи однією із найбільш прибуткових, упродовж багатьох років поспіль характеризується посиленням конкурентної боротьби. В умовах коронавірусної пандемії, яка на діяльності більшості суб'єктів туристичної індустрії позначилася катастрофрічними збитками, спричинила до масових банкрутств, боротьба за споживачів посилилася в рази. Останнім, як відомо, обрати фрірму, яка допоможе їм організувати відпочинок, часто набагато складніше, ніж визначитися 3 місцем відпочинку. Основними критеріями вибору, зазвичай, $є$ ціна, рівень та якість обслуговування, наявність знижки тощо. Численні психологічні дослідження, разом з тим, свідчать, що на вибір туристичного оператора суттєво впливають так звані «приховані умови», основною 3 яких $€$ якість туристичного обслуговування. Як наслідок, стандарт ISO 9001, який засвідчує впровадження у діяльність підприємства принципів системи менеджменту якості, набуває у сорері туризму дедалі більшого значення.

Якість туристичного обслуговування - це сукупність властивостей туристичних послуг, процесів і умов комплексного обслуговування із задоволення обумовлених або передбачуваних потреб туристів під час їхнього відпочинку, подорожей та інших складових туристичного продукту [6]. Забезпечення якості туристичного обслуговування потребує реалізації сукупності системи спланованих заходів. Водночас, виходячи 3 конкурентного характеру туристичного ринку, туристські підприємства повинні також постійно працювати над поліпшенням якості надаваних послуг, з урахуванням стратегічних цілей діяльності, ситуації на ринку, потреб споживачів, інших специфрічних чинників. Проте, як відомо, підприємства індустрії туризму найчастіше використовують лише окремі елементи СУЯ, ігноруючи системний підхід.

Зауважимо, що стандарту ISO 9001 безпосередньо для туристичної галузі, як такого, не існує. Відтак, у разі сертифрікаційного аудиту туристського підприємства застосовуються принципи загального для всіх стандарту ISO 9001, за винятком окремих пунктів, які аналізуються особливо ретельно, натомість деякі інші, навпаки, опускаються. Згідно визначеної процедури, сертифікаційний аудит передбачає здійснення комплексного аналізу туристського підприємства - починаючи 3 роботи 3 документацією і закінчуючи спілкуванням 3 кожним співробітником і проведенням різноманітних опитувань. На основі зібраної інорормації аудитори роблять висновки про те, наскільки на підприємстві застосовуються принципи ISO 9001 і що потрібно зробити, аби відповідати встановленим вимогам. Зроблені висновки та результати перевірки надаються керівництву, яке спільно з аудиторами розробляє план дій та доносить його до всіх співробітників підприємства. По тому починається безпосереднє впровадження стандартів ISO 9001 у діяльність підприємства. Запорукою успіху у цій справі є злагодженість дій сієї команди 3 одночасним дотриманням визначених термінів. Оскільки впродовж періоду сертифрікації туристське підприємство продовжує свою 
роботу, важливо, аби обидва процеси не знижували ефеективність один одного. По завершенню підготовчих робіт туристське підприємство знову проходить сертифікаційний аудит, за результатами якого йому вручається сертифрікат, що підтверджує високий рівень фрункціонування системи менеджменту якості.

Загалом, сертифрікат ISO 9001 для туристського підприємства не $є$ обов'язковим документом, і його керівництво самостійно вирішує, потрібен йому цей документ чи ні. Однак дієвість та ефрективність самої сертифрікації неодноразово була підтверджена на практиці [7].

Висновки. Аудит системи якості менеджменту, як розуміємо, важливий як для споживачів туристських послуг, так і для тих суб'єктів, які їх створюють та реалізовують, для туристичної галузі в цілому, адже засвідчує відповідність їі фрункціонування визначеним принципам. Щоправда, саме по собі успішне проходження аудиту та отримання сертисрікату ISO 9001 не $€$ запорукою вирішення проблем підприємства, адже для того, щоб впроваджені принципи дійсно працювали, необхідною є злагоджена робота всього колективу, дотримання визначених стандартом принципів усіма його членами, від вищої управлінської ланки до нижчої виконавчої. Крім того, зважаючи на існуючі для господарської діяльності в сорері туризму ризики, в т. ч. часті зміни стандартів та інших нормативних актів, аби гідно конкурувати на ринку галузі та розширювати свою на ньому присутність, підприємства туристичної галузі повинні постійно вдосконалюватися. Збільшення кількості нових клієнтів, а заразом фрормування лояльності у тих споживачів, які вже скористалися послугами даного туристського підприємства, можуть бути забезпечені лише шляхом постійного підвищення якості надаваних послуг, перетворення останньої в стійку конкурентну перевагу й запоруку сталого розвитку. Відтак, сертифрікат відповідності вимогам міжнародного стандарту ISO 9001 для туризму - це ознака якості, яку необхідно регулярно підтверджувати.

\section{СПИСОК ВИКОРИСТАНИХ ДЖЕРЕЛ:}

1. Астахов А., Хриплива Л. Система управління якістю - інструмент удосконалення загальної системи управління організацією (підприємством). Стандартизація. Сертифрікація. Якість. 2011. № 4. С. 60-64.

2. Системи менеджменту якості ISO. URL: http://nvppoint.com/uk/sistemi-menedzhmenta-yakosti/

3. Глєбова А.О., Карчевський Б.О. Системи управління якістю на підприємствах в умовах євроінтеграційних процесів. Глобальні та національні проблеми економіки. 2015. Випуск 8. С. 352-356. URL: http://www.global-national.in.ua/archive/8-2015/73.pdf

4. Горбашко Е.А. Управление качеством : учебник. 2-е изд., испр. и доп. Москва : Издательство Юрайт, 2014. 463 с.

5. Баєв В.В. Концептуальні засади менеджменту якості в сорері туризму. Вісник Чернівецького торговельно-економічного інституту. Серія : Економічні науки. 2012. Випуск 3(47). С. 164-169. URL: https://tourlib.net/ statti_ukr/baev.htm

6. Сертификат ISO 9001 в ссрере туризма. URL: https://www.iksystems.ru/a274/

7. Весперіс С.3. Особливості фрормування і управління якістю послуг. Актуальні питання сталого розвитку економіки. 2012. Том 1. С. 75-80.

\section{REFERENCES:}

1. Astakhov A., Khryplyva L. (2011) Systema upravlinnia yakistiu - instrument udoskonalennia zahalnoi systemy upravlinnia orhanizatsiieiu (pidpryiemstvom) [Quality management system - a tool for improving the overall management system of the organization (enterprise)]. Standartyzatsiia. Sertyfikatsiia. Yakist, no. 4, pp. 60-64. (in Ukrainian)

2. Systemy menedzhmentu yakosti ISO [Quality management systems ISO]. Available at: http://nvppoint.com/ uk/sistemi-menedzhmenta-yakosti/

3. Hliebova A.O., Karchevskyi B.O. (2015) Systemy upravlinnia yakistiu na pidpryiemstvakh v umovakh yevrointehratsiinykh protsesiv [Quality management systems at enterprises in the conditions of European integration processes]. Hlobalni ta natsionalni problemy ekonomiky, no. 8, pp. 352-356. Available at: http://www.global-national.in.ual archive/8-2015/73.pdf

4. Horbashko E.A. (2014) Upravlenye kachestvom [Quality management]: uchebnyk. 2-e yzd., yspr. y dop. Moscow: Yzdatelstvo Yurait, 463 p. (in Ukrainian)

5. Baiev V.V. (2012) Kontseptualni zasady menedzhmentu yakosti v sferi turyzmu [Conceptual principles of quality management in the field of tourism]. Visnyk Chernivetskoho torhovelno-ekonomichnoho instytutu. Seriia: Ekonomichni nauky, no. 3(47), pp. 164-169. Available at: https://tourlib.net/statti_ukr/baev.htm

6. Sertyfykat ISO $9001 \mathrm{v}$ sfere turyzma [Certificate ISO 9001 in Tourism]. Available at: https://www.iksystems.ru/a274/

7. Vesperis S.Z. (2012) Osoblyvosti formuvannia i upravlinnia yakistiu posluh [Features of the formulation and management of services]. Aktualni pytannia staloho rozvytku ekonomiky, no. 1, pp. 75-80. (in Ukrainian) 